En cuanto a su repertorio, escribió música preferentemente de cámara, para instrumentos solistas, dúos, tríos, hasta quintetos y octetos. Algunas de sus composiciones, con formato de cámara grande, fueron interpretadas por el Conjunto de Música Moderna, de la Universidad de Chile, dirigido por Roberto Escobar (1974). En su catálogo figuran más de 20 obras, a partir de 1969, incluyendo Sinfonía Ilustración (1970). Editó y publicó 3 discos y, en el último de ellos, Música de cámara, aparece en la portada una foto de su rostro de niño, pintado al óleo por la artista argentina Marta Puebla, quien también participó en las tertulias de su casa familiar.

Selim Kartal, seudónimo que recuerda el universo esotérico de Las mil y una noches, nació el 20 de septiembre de 1945 en Valparaíso, y dejó este mundo recientemente, el jueves 20 de julio de 2017, en Santiago de Chile. Durante su vida siempre buscó ser diferente, apartado de las aglomeraciones humanas, y por ello desde niño evitó participar en los juegos habituales. Como adulto mantuvo esa misma actitud, ejerciendo su pasión creativa como poeta y músico, junto con diversos trabajos esporádicos, sea en calidad de empleado administrativo, vendedor de libros o profesor particular de música y matemáticas, custodiando así su independencia y camino propio.

De allí que en definitiva fuera un hombre solitario. Sin embargo, como contraparte, tenía una rica vida interior, multifacética, pues además de poeta y músico, pintaba a acuarela y témpera, junto con ser amante de la filosofía y la física. Con todo, él tenía un carácter tímido y retraído, aunque igualmente enamoradizo. Gracias a ello se casó y tuvo un hijo, pero su matrimonio no duró más de 2 años. Por otra parte, a nivel institucional, a pesar de su sentido de la libertad, ingresó a la Asociación Nacional de Compositores-Chile (ANC) y de vez en cuando participaba en sus asambleas, constantemente preocupado de estar al día en las cuotas.

Queda claro, entonces, que es difícil encasillar a Ariel Vicuña, desbordante, sea como poeta-músico o como músico-poeta. Y siendo tan especial como era, de bajo perfil, en buena hora supo registrar sus huellas en libros y partituras. Quizás por ello, poco antes de dejar este mundo manifestó estar muy tranquilo y contento con su vida, pacíficamente dispuesto a lo que viniera, sin miedo a la muerte. Así partió y se atrevió a continuar con una nueva aventura, más allá de las miles de noches que vivió en esta Tierra, ahora inmerso en otras esferas poético-musicales, siempre único y especial.

Gabriel Matthey Correa

Compositor, Chile

gmattheyc@hotmail.com

\title{
Coriún Aharonián \\ (Montevideo, 4 de agosto de 1940 - 8 de octubre de 2017)
}

En 1966 tuve la suerte de conocer a Coriún Aharonián. Se realizaba en Concepción (Chile) un curso de verano relativo a dirección coral y un festival nacional de coros organizados por la Asociación Coral Chilena en Santiago, junto con la Universidad de Chile ${ }^{1}$. Coriún, por entonces, era un joven director de coros uruguayo de 26 años, que había estudiado tempranamente musicología con Lauro Ayestarán, por quien tenía gran admiración y respeto. Además trabajó composición musical en su país con Héctor Tosar a partir de 1955 y posteriormente lo hizo con Luigi Nono gracias a una beca del gobierno de Italia.

Para resolver el problema del alojamiento de Coriún en la zona central de Santiago, asegurándonos que quedara cerca del teatro donde se realizaría el festival, me pareció que lo más adecuado era

1 El mismo Aharonián recordó cómo conoció al maestro García en RMCH LVII/200 (juliodiciembre 2003), p. 85. Referencias a aquel curso de verano en dirección coral, donde Aharonián estudió con Marco Dusi, en RMCHXX/95 (enero-marzo 1966), p. 57 (N. del E.). 
llevarlo a mi departamento, donde estaría cómodo, solo y próximo a la sede de la actividad coral, en tanto yo me trasladaría a la casa de mis padres.

Esa visita de Coriún a Santiago generó una muy firme relación de amistad entre nosotros, la que, con los años, se fue fortaleciendo, pues con frecuencia nos encontrábamos en los diversos países, en las más variadas actividades musicales a las que éramos invitados. Asimismo, mantuvimos siempre una muy activa relación epistolar a la que se sumó en su momento la notable compositora e investigadora argentina-uruguaya Graciela Paraskevaídis, su esposa, también desafortunadamente fallecida a comienzos de este año².

Coriún Aharonián nació en Montevideo el 4 de agosto de 1940, fue hijo de padres que sobrevivieron al genocidio armenio en 1915-1923 y llegaron a Uruguay en los años veinte. Coriún comenzó sus estudios de piano cuando tenía cinco años de edad. Varios años después dejó ese instrumento y se inclinó por la dirección coral, convirtiéndose, a los 15 años, en asistente del director de su coro. Más tarde, entre 1966 y 1969, estudió dirección orquestal con Jacques Bodmer, discípulo de Hermann Scherchen. Si a lo anterior sumamos sus estudios de musicología y composición a que hemos hecho referencia y los numerosos cursos y becas de perfeccionamiento que realizó en diferentes países cada vez que tuvo la oportunidad, como fue la beca que recibió en 1969 del Centro Latinoamericano de Altos Estudios Musicales del Instituto Di Tella (CLAEM) de Buenos Aires, entenderemos por qué fue nombrado secretario general de la Sociedad Uruguaya de Educación Musical, así como profesor de institutos de música y pedagogía. Así llegó a ser tempranamente, en 1966, cofundador del Núcleo Música Nueva, al año siguiente fue nombrado Secretario de la Sociedad Uruguaya de Música Contemporánea (SUMC), de 1985 a 1989 fue miembro del Consejo Presidencial de la Sociedad Internacional de Música Contemporánea (SIMC) y fue director honorario del Centro Nacional de Documentación Musical Lauro Ayestarán. Como se ve, su sólida formación musical fue felizmente aprovechada en su país natal, y también lo fue en parte en el resto de los países de América Latina, ya que para Coriún la música de nuestro continente era un tema fundamental, preocupándose tanto de la música de tradición escrita como de aquella de tradición oral, y del papel que estas juegan en el desarrollo social de los habitantes de las tierras de América. En algún momento manifestó:

"Siento que pertenezco a aquel género de creadores cuya función no consiste en ser meramente un adorno social, sino que son conscientes de su responsabilidad histórica. Cultura es lo que refleja a la sociedad y le es útil; lo demás son caprichos individuales"3.

Afortunadamente Coriún pudo transmitir sus convincentes ideas, pues desarrolló un intenso trabajo docente en América, así como en Asia y Europa. Entre 1971 y 1989 colaboró muy directamente en los Cursos Latinoamericanos de Música Contemporánea (CLAMC), donde vació, como en otras oportunidades, pero tal vez con más énfasis, sus reflexiones ideológicas en torno al colonialismo que ha sufrido y sufre la música en Latinoamérica. Como es natural, sus planteamientos teóricos los podemos encontrar en numerosos libros que publicó, todos ellos reeditados. Sus títulos son: Héctor Tosar, compositor uruguayo (1991), Conversaciones sobre música, cultura e identidad (1992), Introducción a la música (2002), Músicas populares del Uruguay (2007) y Hacer música en América Latina (2012). Igualmente, numerosísimos artículos suyos fueron editados en distintas publicaciones, entre ellas la Revista Musical Chilena en la que figuran a lo menos trece colaboraciones entre 1968 y 2009.

Pero Coriún es especialmente conocido por los aficionados a la música por su actividad como compositor, ya que sus obras han sido ejecutadas en más de 30 países y muchas de ellas grabadas. Posee un extenso catálogo que contempla música de cámara para instrumentos solos, conjuntos instrumentales diversos, música electrónica y música para teatro y cine. Asimismo, posee arreglos de música popular para grabaciones de piezas de Daniel Viglietti, de Los Olimareños y otros.

Se sostiene que la obra de Coriún tiene connotaciones ético-sociales, que nacen de su postura política, al igual que de su búsqueda de una identidad latinoamericana que se esconde tras la influencia de la música europea. Sin embargo, esto no impidió que el compositor aprovechara los avances tecnológicos del discurso musical logrado en el viejo continente. Tanto así, que en su catálogo figura un

2 Graciela Paraskevaídis falleció en Montevideo el 21 de febrero de 2017 (N. del E.).

3 Monika Fürst-Heidtmann, "Militancia cultural. El compositor latinoamericano Coriún Aharonián”. Pauta. Cuadernos de teoría y crítica musical, XXI/82 (abril-junio, 2002), pp. 5-27. 
número importante de música electroacústica del mayor interés y con original tratamiento, en que se mezclan, en ocasiones, el sonido de los instrumentos propios de nuestro continente y los producidos por la tecnología.

Difícil será reemplazar en la vida musical americana a Coriún Aharonián, pues siempre encontró la manera de impulsar en los distintos países de América Latina el desarrollo de tendencias en las actividades musicales de esas naciones que se inclinaran hacía lo propio, hacia lo local.

Fernando García Arancibia Academia Chilena de Bellas Artes Instituto de Chile academiachilenadebellasartes@gmail.com 